\title{
A Functional Role for ADAM10 in Human Immunodeficiency Virus Type-1 Replication
}

\author{
Brian M Friedrich ${ }^{1 \dagger}$, James L Murray ${ }^{2 \dagger}$, Guangyu Li ${ }^{1}$, Jinsong Sheng ${ }^{3}$, Thomas W Hodge ${ }^{2}$, Donald H Rubin ${ }^{3,4}$,
} William A O'Brien ${ }^{1,2,5}$ and Monique R Ferguson ${ }^{1 *}$

\begin{abstract}
Background: Gene trap insertional mutagenesis was used as a high-throughput approach to discover cellular genes participating in viral infection by screening libraries of cells selected for survival from lytic infection with a variety of viruses. Cells harboring a disrupted ADAM10 (A Disintegrin and Metalloprotease 10) allele survived reovirus infection, and subsequently ADAM10 was shown by RNA interference to be important for replication of HIV-1.

Results: Silencing ADAM10 expression with small interfering RNA (siRNA) 48 hours before infection significantly inhibited HIV-1 replication in primary human monocyte-derived macrophages and in CD4 ${ }^{+}$cell lines. In agreement, ADAM10 over-expression significantly increased HIV-1 replication. ADAM10 down-regulation did not inhibit viral reverse transcription, indicating that viral entry and uncoating are also independent of ADAM10 expression. Integration of HIV-1 CDNA was reduced in ADAM10 down-regulated cells; however, concomitant 2-LTR circle formation was not detected, suggesting that HIV-1 does not enter the nucleus. Further, ADAM10 silencing inhibited downstream reporter gene expression and viral protein translation. Interestingly, we found that while the metalloprotease domain of ADAM10 is not required for HIV-1 replication, ADAM15 and $\gamma$-secretase (which proteolytically release the extracellular and intracellular domains of ADAM10 from the plasma membrane, respectively) do support productive infection.

Conclusions: We propose that ADAM10 facilitates replication at the level of nuclear trafficking. Collectively, our data support a model whereby ADAM10 is cleaved by ADAM15 and $\gamma$-secretase and that the ADAM10 intracellular domain directly facilitates HIV-1 nuclear trafficking. Thus, ADAM10 represents a novel cellular target class for development of antiretroviral drugs.
\end{abstract}

\section{Background}

Cell homeostasis and ordered proliferation require the interaction of cellular elements that can be assigned to functional pathways. While cells have partial redundancy and regulated expression of components of important cellular pathways, simple pathogens such as viruses appear to be restricted in their interactions. Based upon the hypothesis that disruption of specific cellular proteins would still allow cell and host survival but restrict or inhibit pathogen replication, we have randomly disrupted cellular genes with an insertional mutagen and

\footnotetext{
* Correspondence: mrfergus@utmb.edu

+ Contributed equally

'Departments of Pathology and Internal Medicine, University of Texas

Medical Branch, 301 University Blvd, Galveston, TX, 77555, USA

Full list of author information is available at the end of the article
}

selected for candidate genes whose inactivation allows cell survival following lytic infection. Previously, we reported this strategy was successful in the discovery of several critical host genes, including components of the IGF-II pathway for reovirus and Rab9 for Marburg virus, validating the initial hypothesis [1-3]. Moreover, we reasoned that viruses evolved from common ancestral archetypes might exhibit conserved viral-host protein-protein interactions. Thus, we tested whether candidate genes discovered had broad capability to facilitate replication of viruses from other families and found that disruption of the Rab9 pathway also limited the replication of Ebola virus, measles virus, and HIV-1 [1]. HIV-1 replication requires the assistance of multiple host cell functions for productive infection and several participating cellular factors have been identified. Recent

\section{Biomed Central}


large-scale siRNA screens have revealed hundreds of host factors that participate in a broad array of cellular functions and implicate new pathways in the HIV-1 life cycle [4-8]. Host cell encoded factors are required during every step of virus replication, with the possible exception of initiation of reverse transcription [9-12].

We identified A Disintegrin And Metalloprotease 10 $(A D A M 10)$ in a gene trap library selected for resistance to lytic infection with reovirus and subsequently found that ADAM10 expression is critical for HIV-1 replication. ADAM10 is a cellular metalloprotease that activates numerous and diverse cellular proteins via proteolytic cleavage. In addition to its metalloprotease domain, it also contains a disintegrin domain, an EGFlike domain, a cysteine-rich domain, a transmembrane domain, and a cytoplasmic domain [13]. ADAM10 is required in $\mathrm{NOTCH}$ signaling during embryogenesis [14]. It also shares some functions with ADAM17 in the cleavage and release of surface bound TNF- $\alpha$, E-cadherin, and other proteins [15-20]. Previous studies have indicated that ADAM10 is found in both the cellular and nuclear membranes [21,22]. It has been shown that a released intracellular fragment (ICF) of ADAM10 is capable of translocating into the nucleus and is potentially important in the nuclear transport of the androgen receptor [21]. Tousseyn and colleagues have shown that this nuclear entry of ADAM10 is dependent upon sequential proteolytic modification, and demonstrated that the ectodomain of ADAM10 is first shed by either ADAM9 or ADAM15 and the intracellular domain is subsequently cleaved by $\gamma$-secretase, releasing the ICF [23].

In studies reported herein, it was found that transfecting cells with ADAM10 small interfering RNA (siRNA) dramatically inhibited replication of X4 and R5 HIV-1 strains, both in primary human monocyte-derived macrophages and in $\mathrm{CD}^{+}$cell lines. Moreover, our data indicate that ADAM10 is critical for post-entry HIV-1 replication events occurring during nuclear trafficking or nuclear entry in human monocyte-derived macrophages and in $\mathrm{CD} 4^{+}$cell lines, and is dependent upon its proteolytic modification. Furthermore, we show that ADAM15 and $\gamma$-secretase are also required for HIV-1 replication, suggesting that the ADAM10 intracellular domain (ICD) is required for nuclear trafficking of HIV-1 to the nucleus.

\section{Results}

Implication of ADAM10 in reovirus replication using gene trap insertional mutagenesis

We have applied gene trap insertional mutagenesis $[1-3,24]$ as a high throughput genetic screen to aid in the discovery of novel genes critical for viral replication.
Cellular alleles are randomly inactivated, and cells surviving an otherwise toxic viral infection harbor a mutated gene, whose wild type counterpart is potentially utilized in the viral life cycle $[1,3]$. To identify targets for broad-spectrum viral inhibition, we determined whether candidate genes implicated in gene trap studies with unrelated viruses serve a functional role in HIV-1 replication. Small interfering RNA (siRNA) was used to knockdown expression of candidate genes, and the effect on HIV infection was determined by assaying HIV-1 p24 production. HeLa cells modified to stably express CD4 and CCR5 (TZM-bl cells) were screened with siRNAs targeting genes trapped with reovirus, influenza A, or Marburg virus $48 \mathrm{~h}$ prior to infection with LAV (X4-tropic). Treatment of TZM-bl cells with siRNA specific for ADAM10 inhibited HIV-1 replication $\sim 90 \%$ ( $\mathrm{n}=4$, data not shown). We also observed that siRNA targeting ERBB2IP did not affect HIV-1 replication, and thus was also used in these studies as a negative control.

\section{ADAM10 silencing inhibits both R5- and X4-tropic HIV-1 replication}

To confirm the requirement of ADAM10 in more physiologically relevant primary cells, human blood-derived macrophages were transfected with siRNAs targeting ADAM10, CD4, or with a scrambled sequence control siRNA, and then infected with the R5 HIV-1 strain SF162. Figure 1A shows that ADAM10 silencing effectively inhibited R5-tropic HIV-1 replication when human monocyte-derived macrophages were transfected with siRNAs $48 \mathrm{~h}$ prior to infection. ADAM10 siRNA inhibition of HIV-1 was similar to that seen with siRNA directed against CD4, the primary cellular receptor for HIV-1 [25].

Interestingly, ADAM10 silencing also inhibited replication of the X4-tropic LAV strain in $\mathrm{CD}^{+}$TZM-bl cells (Figure 1B). ADAM17 is a related metalloprotease which shares partial (but not complete) substrate specificity with ADAM10 [15-20], and has been shown to mediate SARS-CoV envelope shedding [26]. Accordingly, the role of ADAM17 expression in HIV-1 replication was studied by knockdown of expression with RNAi in TZM-bl cells; however, ADAM17 silencing did not significantly inhibit viral replication. These results indicate that ADAM10, but not ADAM17, serves a specific role in the viral lifecycle.

\section{ADAM10 silencing for one week does not affect macrophage viability or function}

ADAM10 siRNA transfectants were confirmed to have significant reductions in ADAM10 protein expression by both flow cytometry in cell lines $48 \mathrm{~h}$ after siRNA transfection (Figure 2A) and Western blot analysis in primary 

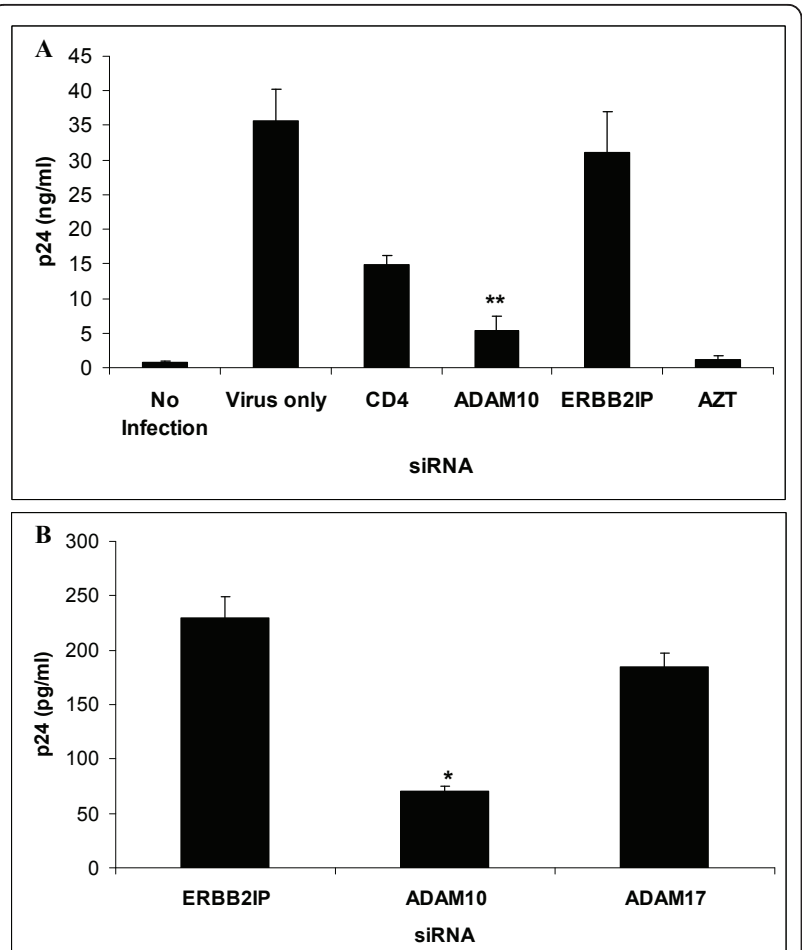

Figure 1 ADAM10 silencing inhibits both CCR5- and CXCR4tropic HIV-1 replication. (A) Primary macrophages were transfected with different siRNAs $48 \mathrm{~h}$ prior to infection with HIVSF162. Azidothymidine (AZT) treatment was used as a positive control to block infection. Supernatants were collected 7 days after infection and HIV p24 production was measured by ELISA. ADAM10 silencing significantly reduced viral replication in primary human macrophages (**P $<0.01$ ). (B) To determine whether ADAM17 also plays a role in HIV-1 replication, TZM-bl cells were transfected with ADAM17, ADAM10 or ERBB2IP siRNAs $48 \mathrm{~h}$ prior to infection with $L A V$, and supernatant HIV p24 was measured by ELISA 3 days after infection $\left({ }^{*} P<0.05\right)$.

macrophages $48 \mathrm{~h}$ after siRNA transfection (Figure 2B). Kinetics of ADAM10 mRNA down-regulation by siRNA was measured using real time PCR in U373-MAGI-CCR5 cells (Figure 2C) and primary human macrophages (Figure 2D). To determine the viability of siRNA-transfected macrophages, cytotoxicity was assayed using GAPDH coupled to 3-phosphoglyceric phosphokinase and measuring ATP [27]. The siRNA transfections resulted in no significant adverse cytotoxic effect $(\mathrm{P}<$ 0.01 ), although dose-dependent cell death was observed when cells were treated with chelerythrine, a Protein Kinase $C$ inhibitor (data not shown). In addition, ADAM10 siRNA-transfected macrophages displayed phagocytic function similar to macrophages transfected with scrambled siRNA, as determined by comparing the phagocytosis of captured bodipy beads [28] (data not shown).

\section{ADAM10 expression is not required for HIV-1 reverse transcription}

To determine whether ADAM10 is required for entry or HIV-1 reverse transcription, small non-genomic DNA was isolated from control- and ADAM10 siRNA-transfected macrophages at $48 \mathrm{~h}$ post-infection for quantification by real-time PCR. Previous studies demonstrated that kinetics of reverse transcription is slower in macrophages than in lymphoid cells, and full-length HIV-1 reverse transcripts are not generated until 36-48 h after infection in macrophages $[29,30]$. Thus, cDNA levels detected at 48 hours post-infection should be reflective of only a single replication cycle. As shown in Figure 3A, ADAM10 silencing did not affect detection of full length HIV-1 cDNA, whereas viral DNA formation was not detected in cells treated with the reverse transcription inhibitor AZT. These data demonstrate that ADAM10 expression is not required for HIV-1 entry and completion of reverse transcription.

\section{ADAM10 activity in HIV-1 replication precedes viral integration}

To determine if ADAM10 is required for proviral DNA integration, genomic and small non-genomic cDNA was isolated from cells at various time points post-infection. If HIV-1 cDNA enters the nucleus but does not integrate into the host cell chromosome, then the viral cDNA circularizes to form a 2-LTR circle [31,32], which can be quantified using real-time PCR. Integration is quantified by using one primer directed against HIV-1 and another primer directed against $A l u$, a common repetitive sequence found in the human genome. Knockdown of ADAM10 significantly reduces the amount of integrated HIV-1 cDNA in both macrophages (Figure 3B) and U373-MAGI-CCR5 cells (Figure 3C). Small non-genomic DNA was isolated from cells after infection to quantify formation of 2-LTR circles. As shown in Figure 3D, 2-LTR circle formation was not observed in macrophages treated with siRNA to ADAM10, whereas when cells were treated with the integrase inhibitor, Raltegravir, 2-LTR circles are detected [33]. Inhibition of both HIV-1 integration and 2-LTR circle formation by ADAM10 siRNA indicates that while HIV-1 cDNA is efficiently generated, it is not efficiently translocated into the nucleus of ADAM10 down-regulated cells.

ADAM10 is utilized for steps prior to HIV-1 tat expression To confirm that ADAM10 function is not required for HIV-1 replication events following integration, U373MAGI-CCR5 cells were used in reporter gene assays to gauge the effect of ADAM10 silencing on Tat function. Tat function was measured by $\beta$-galactosidase $(\beta$-gal) 


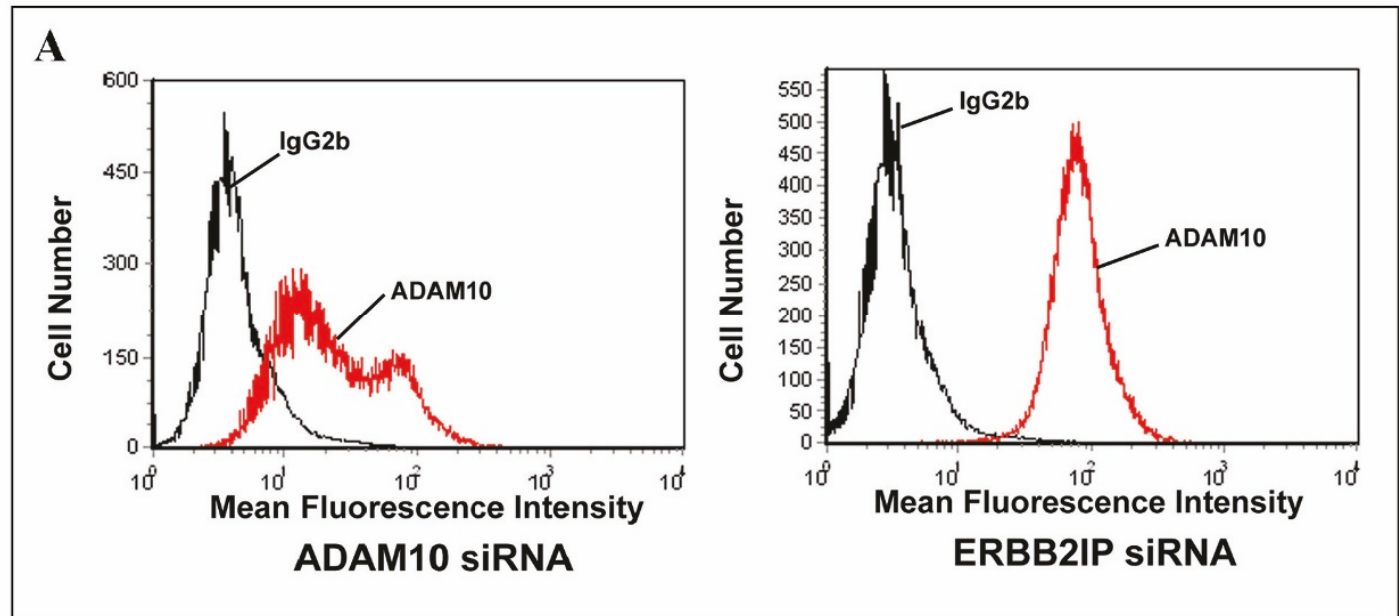

B

No siRNA Control ADAM10

ADAM10
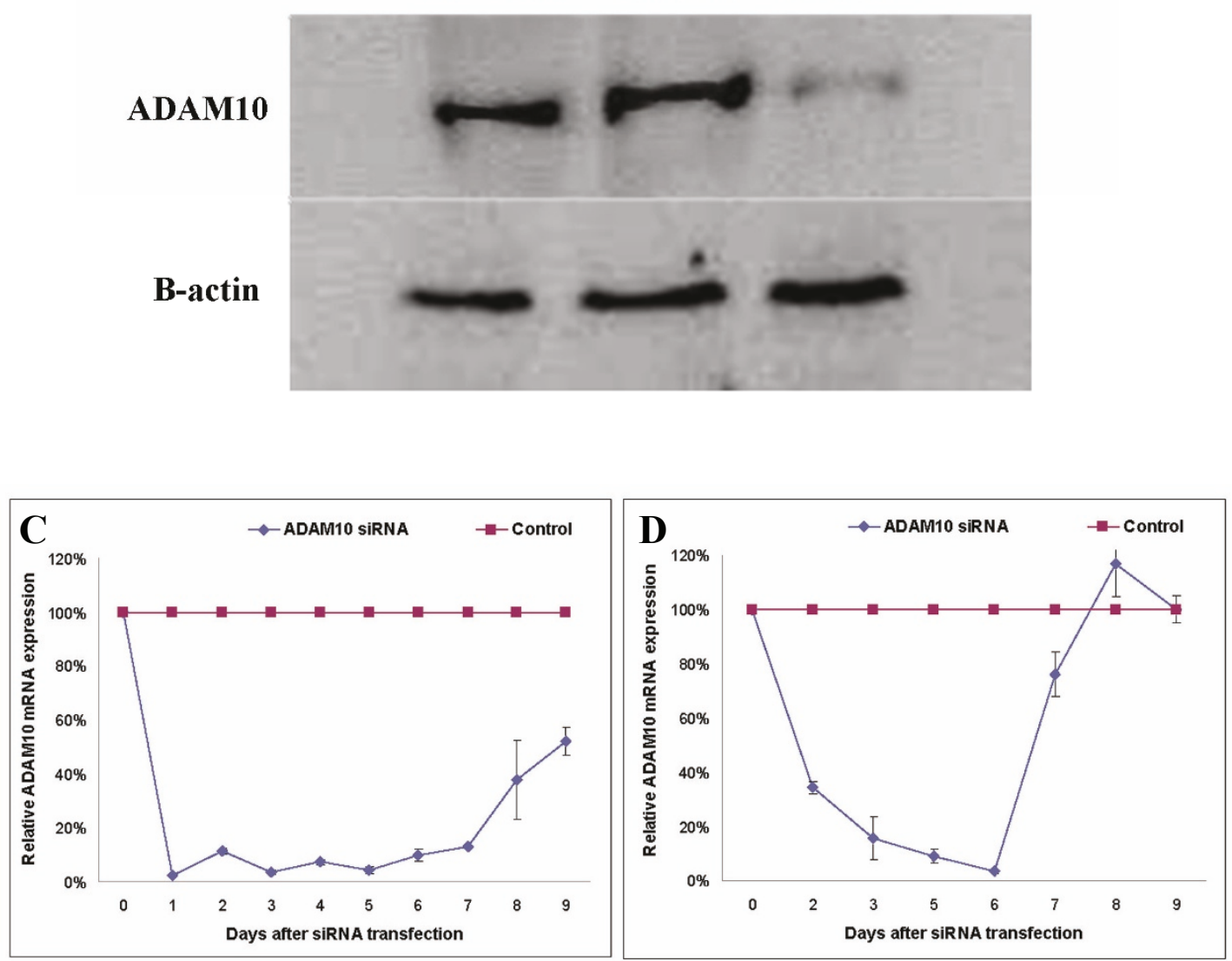

Figure 2 ADAM10 silencing persists for one week following siRNA transfection. Assessment of ADAM10 expression following RNAi by (A) flow cytometry in TZM-bl cells 48 hours after transfection, (B) Western blot in primary human macrophages 48 hours after transfection, and real time PCR in (C) U373-MAGI-CCR5 cells and (D) primary human macrophages at various times after siRNA transfection. Relative levels of ADAM10 mRNA expression in siRNA transfectants were normalized to GAPDH expression $(n=4)$. 


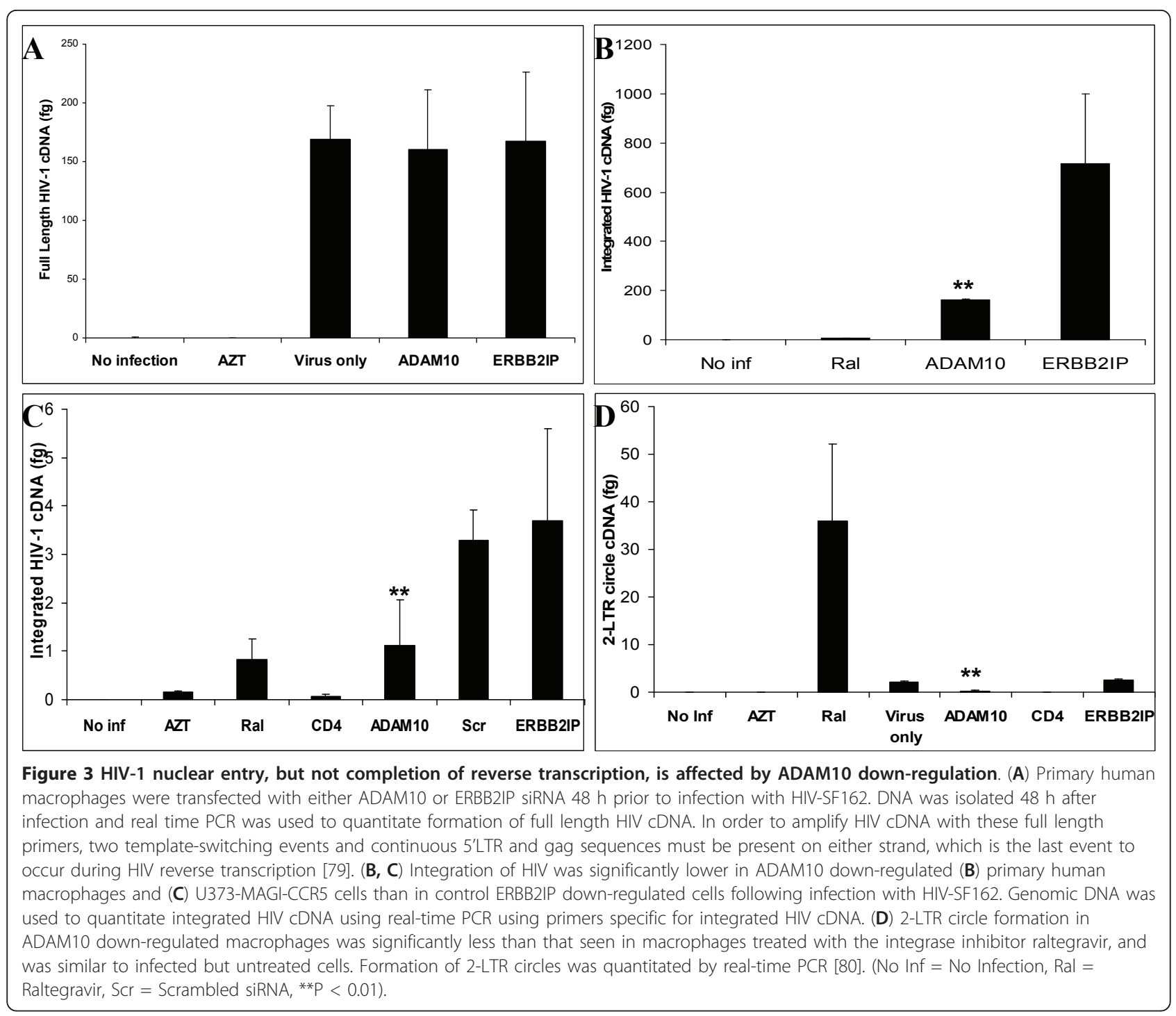

activity expressed from a stably integrated HIV-LTR- $\beta$ gal construct [34]. As shown in Figure 4A, Tat activity was robust in ERBB2IP control siRNA-transfected and HIV-1 infected, but not transfected (virus only), cells at $72 \mathrm{~h}$. Tat activity in ADAM10 or CD4 siRNA-transfectants at $72 \mathrm{~h}$ post-infection was similar to the background levels seen at Day 0. However, Tat activity was unaffected by ADAM10 silencing when U373-MAGICCR5 cells were transfected with a plasmid encoding recombinant Tat (Figure 4B), indicating that ADAM10 does not directly activate Tat and that ADAM10 affects virus replication prior to Tat transcription or translation. In agreement, Western blots revealed that production of the viral Env and p24 proteins were significantly inhibited between days 4-7 post-infection in primary macrophages following ADAM10 silencing (data not shown).
Additionally, the role of ADAM10 was studied in TZM-bl cells transfected with a plasmid-based molecular clone (pNL4-3) or infected with the corresponding HIVNL4-3 virus. Although replication of HIV-NL4-3 was dramatically inhibited in ADAM10 siRNA-transfectants, ADAM10 was not required in the plasmid-based system (Figure 4C). The pNL4-3 plasmid has a $15 \mathrm{~kb}$ insert that includes a full-length proviral clone and one to two kb of flanking cellular sequence outside both the 5' and 3' LTR and very efficiently directs HIV gene expression following transfection, independent of plasmid integration. Thus, the plasmid serves as a surrogate for proviral integration, bypassing the normal early events of the viral life cycle (Figure 4D). Additionally, we used a U1 cell line, which contains two integrated copies of the HIV-1 proviral genome, and can be induced to produce progeny virus following treatment with a phorbol ester $[35,36]$. 


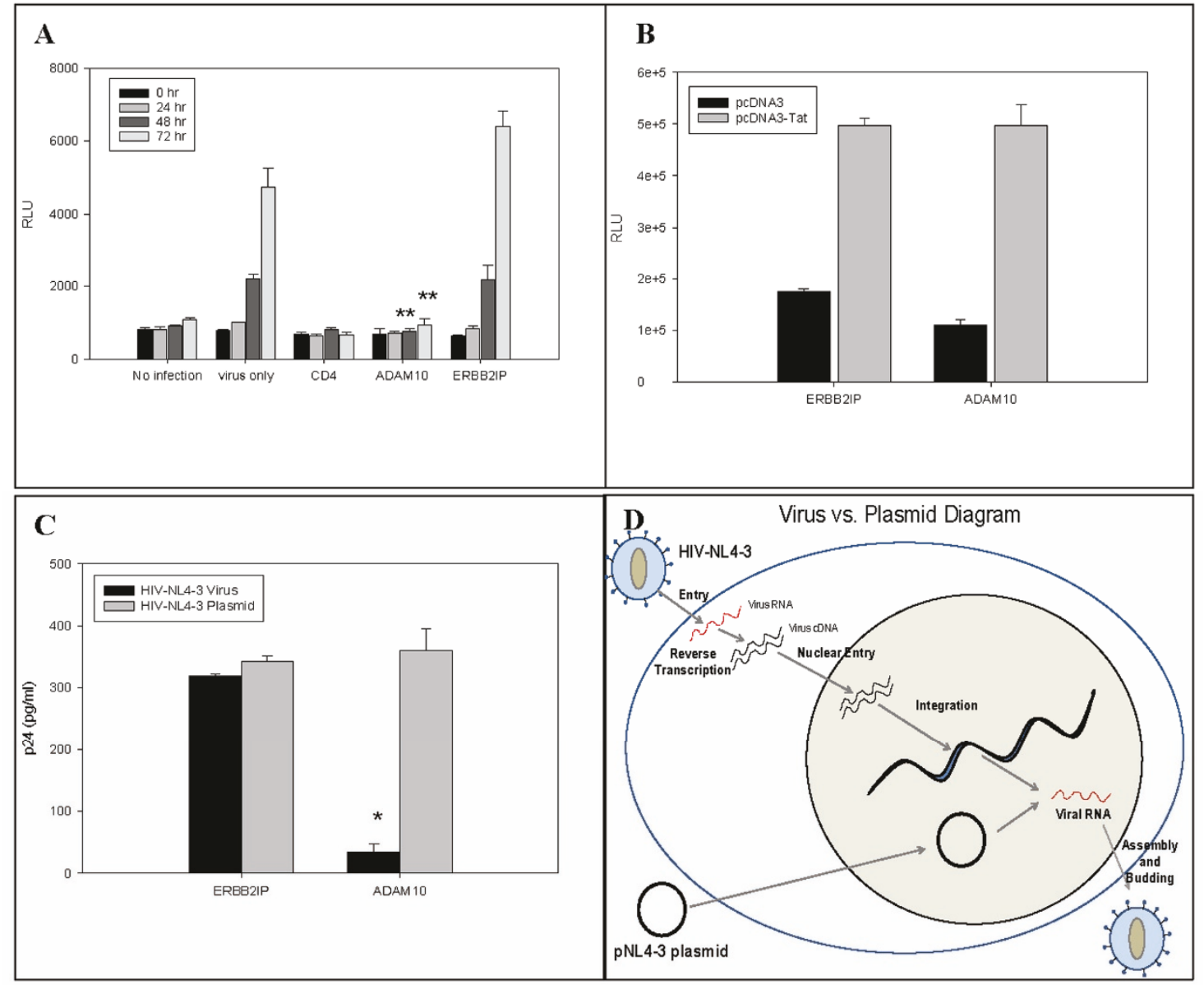

Figure 4 ADAM10 down-regulation inhibits Tat-dependent HIV-1 replication steps. (A) ADAM10 down-regulation with siRNA affects Tatdependent $\beta$-galactosidase production in U373-MAGI-CCR5 cells after infection with HIV-SF162. $\beta$-galactosidase was measured by fluorescence at various time points after infection (**P < 0.01). (B) ADAM10 does not directly activate Tat. After either ADAM10 or ERBB2IP down-regulation, U373-MAGI-CCR5 cells were transfected with a plasmid encoding recombinant Tat, indicating that ADAM10 affects virus replication prior to Tat transcription or translation. $\beta$-galactosidase is expressed as RLUs (Relative Light Units). (C) ADAM10 down-regulation significantly reduces HIV p24 production in virally infected but not HIV plasmid-transfected TZM-bl cells. ADAM10 down-regulation affected viral replication in HIV-NL4-3 infected cells, but not in cells transfected with pNL4-3, a plasmid expressing the full length NL4-3 molecular clone $\left({ }^{*} P<0.05\right)(\mathbf{D})$ Diagram illustrating the different processes for virus production in the virus vs plasmid experiment. Viral mRNA can be directly transcribed from the pNL43 plasmid, while virus infection must go through entry, reverse transcription, nuclear entry, and integration to produce viral RNA.

Down-regulation of ADAM10 had no effect on production of HIV-1 in these cells (data not shown). These data indicate that ADAM10 supports virus replication prior to gene transcription. Taken together, these data suggest that the function of ADAM10 in HIV-1 replication is bracketed between the levels of nuclear trafficking and nuclear entry.

\section{A functional ADAM10 metalloprotease is not required for HIV-1 replication}

To determine whether over-expression of ADAM10 increases HIV-1 replication and infection, we obtained a human ADAM10 plasmid from Dr. Stefan Lichtenthaler (LMU Munich, Germany). As shown in Figure 5A, over- expression of ADAM10 resulted in increased HIV-1 replication. The metalloprotease domain potentially responsible for this increase was further investigated. ADAM10 E384A plasmid contains a single inactivating point mutation in the metalloprotease domain rendering the metalloprotease domain inactive [37]. ADAM10 E384A and wild type (wt) ADAM10 plasmids were transfected into U373-MAGI-CCR5 cells $48 \mathrm{~h}$ prior to infection with HIV-SF162 $(\mathrm{MOI}=0.1)$. As shown in Figure 5B, over-expression of ADAM10 E384A showed an increase in HIV-1 replication very similar to that seen with wt ADAM10 over-expression, suggesting that the metalloprotease domain is not the critical domain in ADAM10 supporting HIV-1 infection. In addition, tissue 

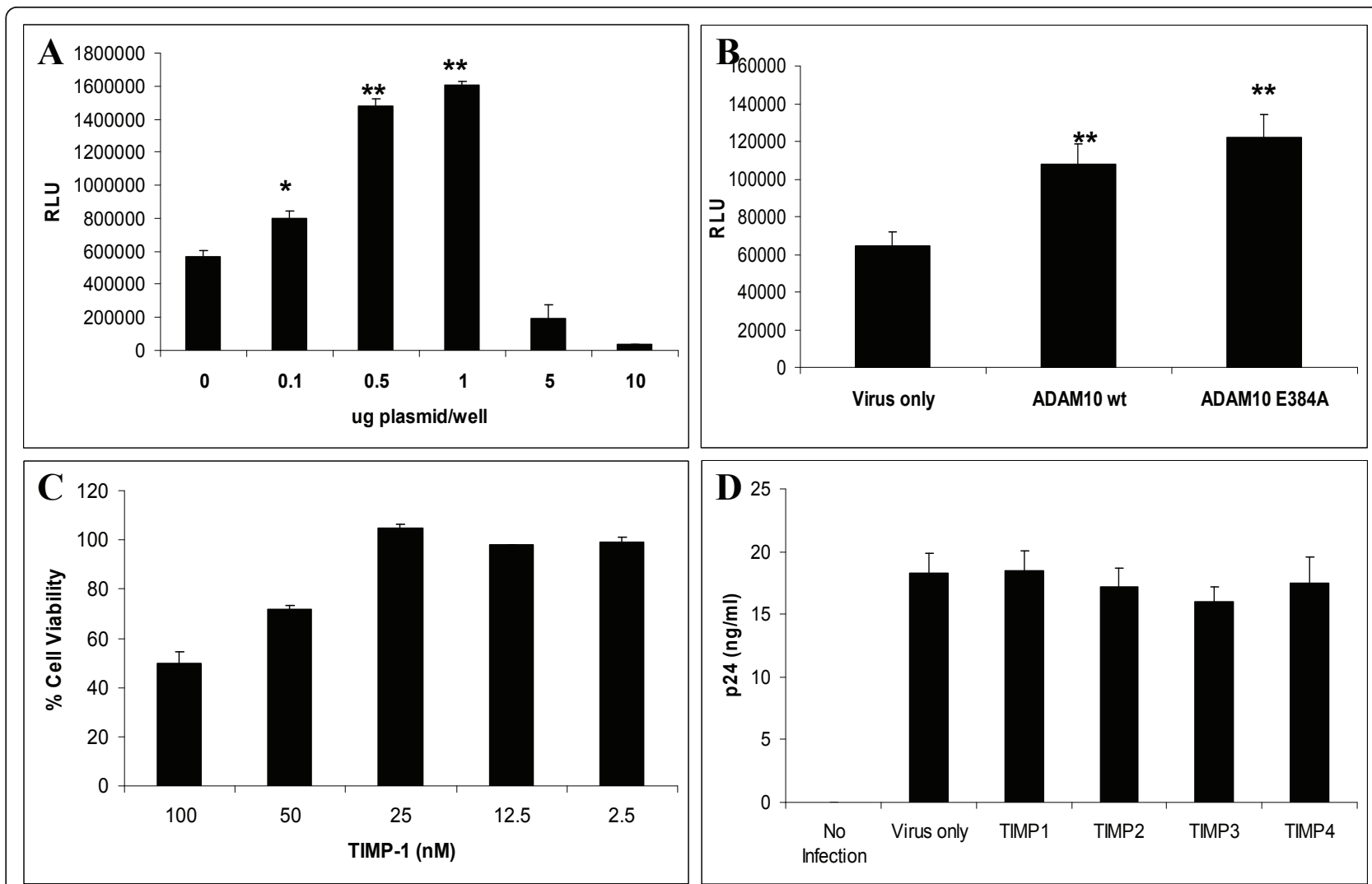

Figure 5 A functional ADAM10 metalloprotease domain is not required for HIV-1 replication. (A) Over-expression of wt ADAM10 in U373MAGI-CCR5 cells increased HIV-1 replication; however, cell toxicity was noted at concentrations of $0.5 \mu \mathrm{g}$ and above. $\beta$-galactosidase activity was measured $48 \mathrm{~h}$ after infection ( ${ }^{*} \mathrm{P}<0.05,{ }^{*} \mathrm{P}<0.01$ ). (B) Over-expression of wt ADAM10 and ADAM10 E384A both increased HIV-1 replication U373-MAGI-CCR5 cells. $0.5 \mu \mathrm{g}$ of DNA plasmid was transfected into U373 cells and infected with HIV-SF162 48 hours after transfection. Cells were lysed and $\beta$-galactosidase activity was measured $48 \mathrm{~h}$ after infection ( $* \mathrm{P}<0.05)$. (C) Serial dilutions of tissue inhibitors of metalloprotease 1 (TIMP-1) were added to primary macrophages, and cell viability was assessed $24 \mathrm{~h}$ after addition of TIMP-1. (D) TIMPs had no effect on HIV-1 replication in primary human macrophages. TIMPs $(25 \mathrm{nM})$ were added to primary macrophages $24 \mathrm{~h}$ prior to and during infection with HIVSF162. Supernatant was collected $7 \mathrm{~d}$ after infection and HIV-1 p24 production was measured by ELISA.

inhibitors of metalloproteases (TIMPs) 1 and 3, which have been shown to inhibit ADAM10 metalloprotease activity [38], had no effect on HIV-1 replication in human macrophages (Figure 5C, D). This indicates that the ADAM10 metalloprotease domain is not functionally required for HIV-1 replication.

\section{Both $\gamma$-secretase and ADAM15 are required for HIV-1 replication}

To determine if the intracellular domain of ADAM10 plays a role in HIV-1 replication, we independently inhibited the two necessary proteolytic steps that free this fragment. ADAM9 and ADAM15 were shown to cleave the ectodomain of ADAM10 while $\gamma$-secretase has been shown to cleave and release the ADAM10 intracellular domain (ICD) [23]. Once released, the ADAM10 ICD can then translocate to the nucleus or peri-nuclear region $[21,23]$. To determine whether ADAM9 and/or ADAM15 were required for HIV-1 replication, cells were transfected with siRNAs directed against either ADAM9 or ADAM15 mRNA prior to infection. As shown in Figure 6A, ADAM15 siRNA significantly reduced HIV-1 replication, comparable to the level of replication seen with knockdown of ADAM10, whereas ADAM9 knockdown had no effect on HIV-1 replication. Next, we studied the role of $\gamma$-secretase, a multi-subunit complex, containing presenilin, nicastrin, anterior pharynx-defective 1 (APH-1), and presenilin enhancer protein 2 (PSEN) [39], in HIV-1 replication. $\gamma$ secretase contains either the presenilin-1 (P1) or presenilin-2 (P2) isoform, which contributes to the substrate specificity of the enzyme [40]. To determine if $\gamma$-secretase is required for HIV-1 replication, siRNA targeting different components of $\gamma$-secretase was used to inhibit the enzyme. As shown in Figure 6B, siRNA targeting P2, nicastrin, and PSEN all significantly decreased HIV-1 replication in U373 cells. However, P1 siRNA did not affect HIV-1 replication. These data show a specific role 

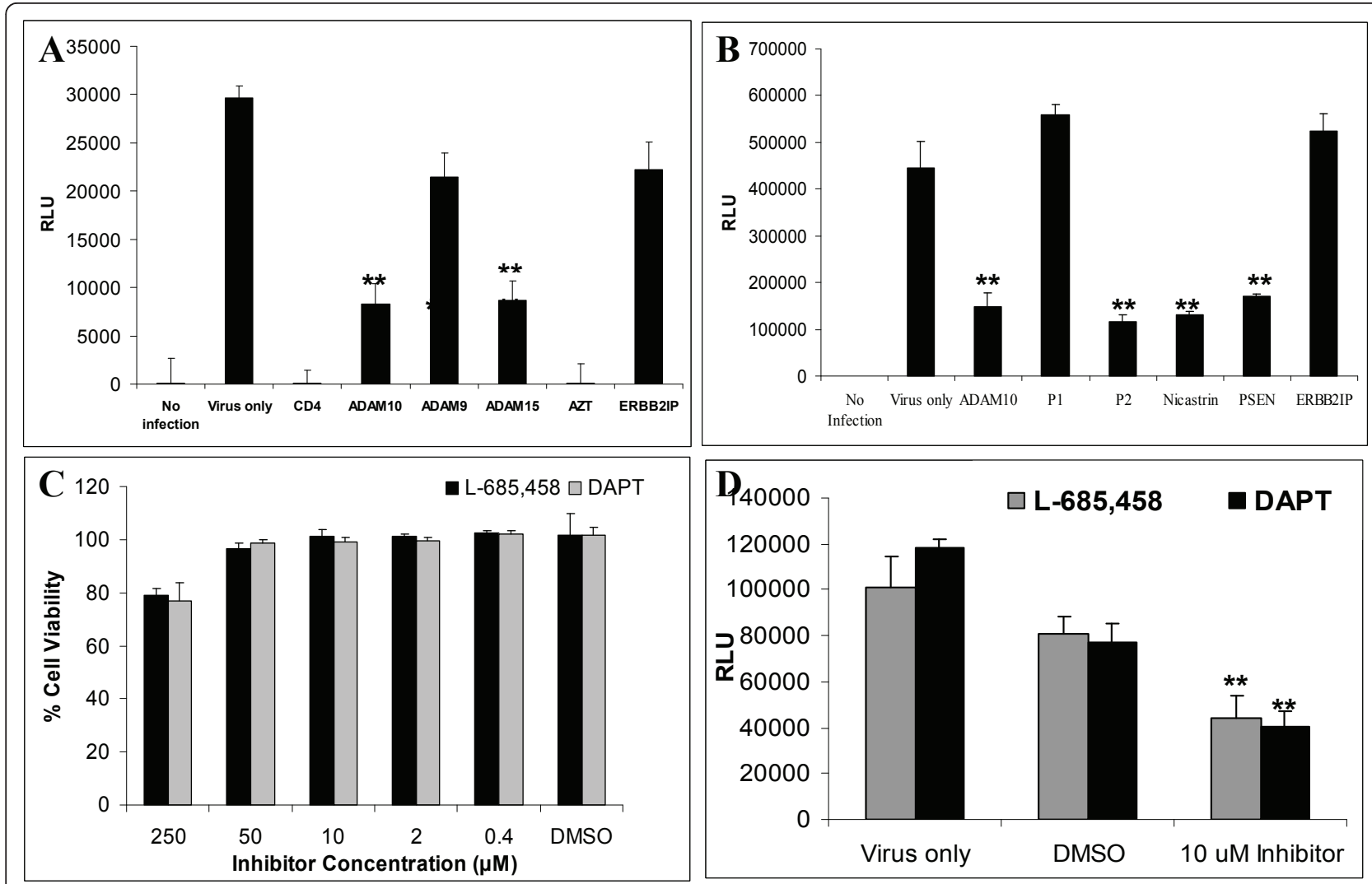

Figure 6 ADAM15 and $\gamma$-secretase are required for HIV-1 replication. (A) ADAM15 downregulation significantly reduced HIV-1 replication in U373-MAGI-CCR5. However, ADAM9 downregulation did not affect HIV-1 replication. U373 cells were transfected with siRNA and $\beta$-galactosidase was measured $48 \mathrm{~h}$ after infection with HIV-SF162. (B) Down-regulation of $\gamma$-secretase subunits significantly decreased HIV-1 replication. Presenilin-2, not presenilin-1, is specifically required for HIV-1 replication ( $11=$ presenilin-1, $P 2=$ presenilin-2, PSEN = presenilin enhancer protein 2 , **P < 0.01). $\beta$-galactosidase was measured $48 \mathrm{~h}$ after infection with HIV-SF162. (C) Serial dilutions of $\gamma$-secretase inhibitors (L-685,458 and DAPT) were added to the cells, and cell viability was assessed $24 \mathrm{~h}$ after addition of inhibitors. (D) L-685,458 and DAPT significantly reduced $\beta$ galactosidase in U373-MAGI-CCR5 cells compared to DMSO controls. $\beta$-galactosidase activity was measured $48 \mathrm{~h}$ after infection with HIV-SF162 $\left.{ }^{* *} P<0.01\right)$.

of presenilin-2, and not presenilin-1, in HIV-1 replication. Additionally, we used specific $\gamma$-secretase inhibitors, L-685,458 and DAPT $[41,42]$. Cytotoxicity assays were performed to determine optimal, sub-toxic concentrations for either inhibitor (Figure 6C). Figure 6D shows that adding $10 \mu \mathrm{M}$ of either L-685,458 or DAPT to U373 cells $24 \mathrm{~h}$ prior to infection and during infection, significantly decreased HIV-1 replication as compared to DMSO-only treatment and infection only controls. These findings confirm that $\gamma$-secretase is required for HIV-1 replication. Taken together, both ADAM15 and $\gamma$-secretase facilitate HIV-1 replication, consistent with their roles in the release of the ADAM10 intracellular domain.

\section{Discussion}

We utilized gene-entrapment of diploid cell lines for our initial selection of candidate genes associated with cell survival following lytic virus selection. Several possible outcomes may result, including haploid insufficiency, complete loss of expression from a vector inserted into a dominant allele [43-45], or dominant negative effects due to truncated translational products $[46,47]$. Furthermore, siRNA can be used as a confirmatory step across a wide variety of cell types and viruses, once a candidate gene is identified, as we reported for HIV-1 infection [1]. In this study, we identified $A D A M 10$ by gene trap insertional mutagenesis as a disrupted gene in cells surviving cytolytic reovirus infection, and we demonstrated the importance of ADAM10 expression at a post-entry step in HIV-1 replication. We also show that overexpression of ADAM10 increases HIV-1 replication. Interestingly, in previous studies solely using siRNA or shRNA to identify cellular proteins required for HIV-1 replication [4-7], Brass et al. had also identified ADAM10 as a required cellular gene [4]. Importantly, these studies show that ADAM10 silencing inhibits HIV-1 in primary human macrophages, which are more 
relevant to human disease than tissue culture adapted cell lines [48]. Macrophages and $\mathrm{CD}_{4}^{+}$lymphocytes are the predominant cell types infected with HIV-1 clinically, and the importance of ADAM10 in HIV-1 replication in primary human macrophages supports a role of ADAM10 in HIV-1 pathogenesis.

To determine the precise step in HIV-1 replication in which ADAM10 participates, we inhibited various processes and queried for viral products that define steps up to and including virus expression from chromosomally integrated viral DNA. Our data supports a role for ADAM10 at a step in virus replication prior to integration. HIV-1 must enter the cell and be partially disassembled prior to reverse transcription of viral cDNA, and these steps are not inhibited with knockdown of ADAM10. It was found that ADAM10 silencing resulted in a failure of viral cDNA to integrate, as measured by real time PCR. Moreover, HIV-1 2-LTR circles did not accumulate in the nucleus, which occurs after virus enters the nuclear membrane but cannot integrate. It is known that 2-LTR circles accumulate when integration is inhibited with specific integrase enzyme inhibitors [33]. Furthermore, ADAM10 silencing did not affect Tat-dependent proviral gene expression as assessed in studies using a plasmid expressing Tat and Tat-dependent $\beta$-galactosidase expression. Using pNL4-3, a plasmid containing the HIV-1 genome, knockdown of ADAM10 did not limit virus transcription, consistent with its role prior to viral transcription from integrated proviral DNA. Our data are supportive of an important role for ADAM10 in HIV-1 replication at a step following reverse transcription but prior to HIV-1 integration, likely at the level of nuclear trafficking.

A role for ADAM10 during nuclear trafficking is in concert with known cellular roles for this complex protein. The protein has several known extracellular domains, which include a metalloprotease domain, an integrin binding domain, and a cysteine rich region. A recent study has shown ADAM10 to be essential for cell entry of Plasmodium falciparum due to its interaction with the malaria PfSUB2 enzyme [49]. ADAMs function in the proteolytic release of many transmembrane cell surface cytokines, growth factors, receptors, and adhesion proteins, a process known as ectodomain shedding. ADAM10 is known to cleave over 20 cell surface proteins [15-20,50-68]. Most known ADAM10 substrates are involved in cellular adhesion, including ephrin-A2 (EFNA2), AXL, fractalkine (CX3CL1), CXCL16, E- and N-cadherin (CHD1 and 2), the $\gamma$-protocadherins C3 and B4, NCAM, CHL1, LAG-3, CD23, CD44, CD46, and desmoglein-2 (DSG2). However, while there is known promotion of trans-infection of HIV-1 secondary to interaction with the adhesion molecules, C-type lectins DC-SIGN and DC-SIGNR
$[69,70]$, the data presented above do not support a role in cell entry for ADAM10. Surprisingly, the metalloprotease function was not required for HIV-1 replication. More recently, activity has been attributed to the $6 \mathrm{kDa}$ fragment released from the carboxy-terminus. This fragment is released from the intracellular domain following sequential proteolytic digestion. ADAM9 and -15 have been shown to be responsible for releasing the ADAM10 ectodomain, while presenilin $/ \gamma$-secretase has been shown to be responsible for the proteolytic release of the ADAM10 intracellular domain from the plasma membrane, whereupon it localizes to the nucleus [23]. Cleavage and release of the ADAM10 ectodomain are required for the intracellular domain to be subsequently released. We demonstrate that both ADAM15 and $\gamma$-secretase are required for HIV-1 replication, which strongly suggests the intracellular domain of ADAM10 is critical for HIV-1 replication. We did not find ADAM9 to be required for HIV-1 replication in our assays. Whether this is unique to the cell line used in our assays, as ADAM10 can be alternatively spliced, or rather that ADAM15 is specifically required by HIV-1, requires further study.

\section{Conclusions}

ADAM10 has a role in androgen receptor nuclear translocation and has been shown to translocate to the nuclear and the perinuclear region during prostate cancer pathogenesis and progression [21]. Combined with our data showing that ADAM10 functions during nuclear trafficking or nuclear entry, we suggest that the intracellular domain may either function to promote trafficking of HIV-1 PIC to the nucleus (Figure 7), or serve a scaffolding role during PIC assembly. The relationship between ADAM10 intracellular domain and HIV-1 PIC needs further study. It is possible that the ICD directly interacts with HIV-1 viral proteins or nucleic acid, or it is essential for another host component that traffics the PIC through the nuclear pore. Studies are ongoing to determine its precise role in HIV-1 entry into the nucleus. It is intriguing to note that ADAM10 is not the only ADAM protein that has dual functionality, as Cousin et al. have found that the nuclear translocation of the ADAM13 intracellular domain is required for gene expression and neural crest cell migration [71]. Whether this class of proteins participates in the replicative cycle for other virus may deserve further study.

These studies utilized both primary human macrophages and tissue culture adapted cell lines that have been extensively used in the study of HIV-1. Primary macrophages with knockdown of ADAM10 were viable and functionally active, thereby raising the possibility that inhibition of ADAM10 processing or targeting the 


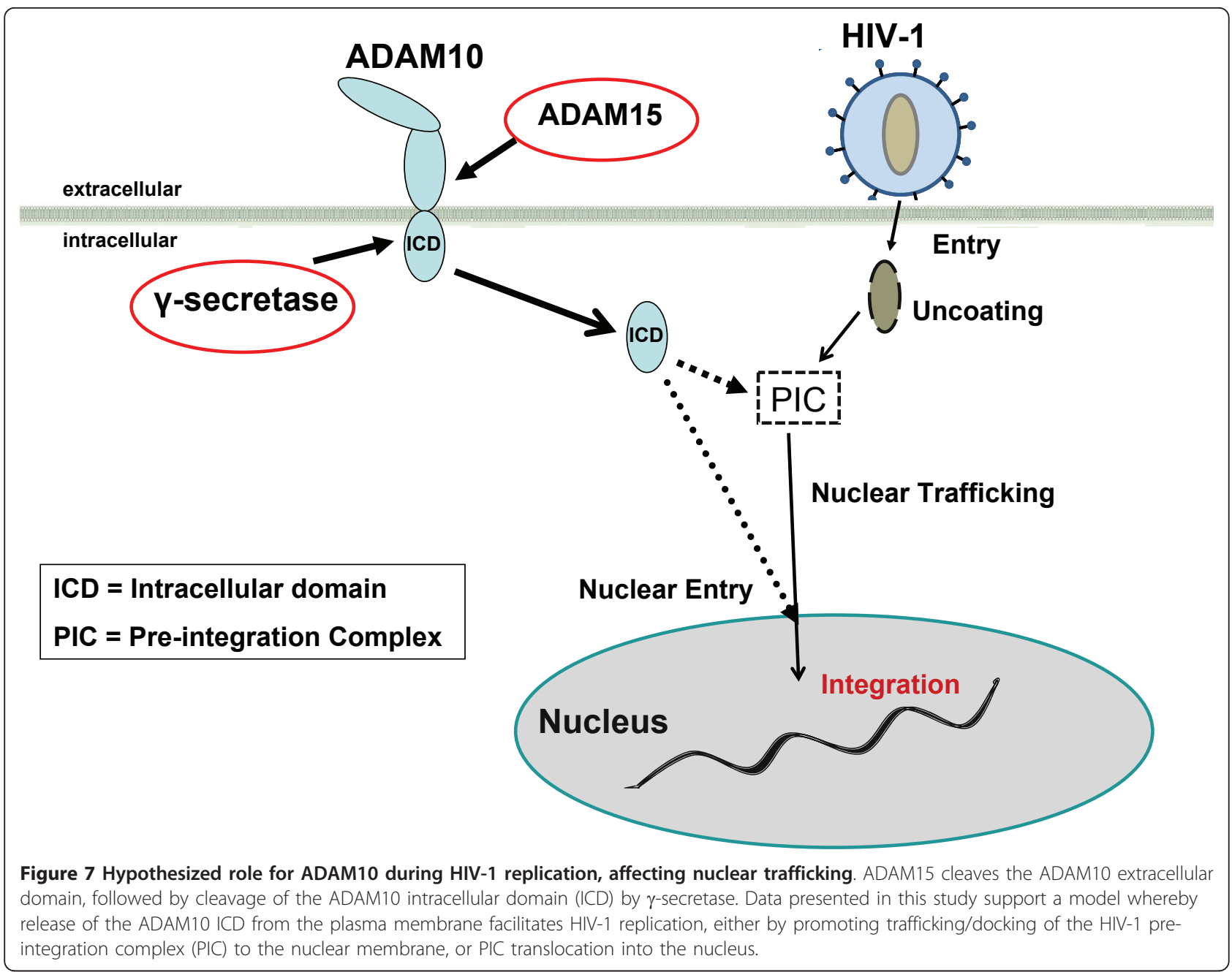

intracellular fragment could lead to new set of potential therapeutic targets.

\section{Methods}

Cells, viruses, and reagents

Monocyte-derived human macrophages were prepared from leukopaks obtained from the University of Texas Medical Branch Blood Bank (Galveston, TX). Peripheral blood mononuclear cells were recovered from leukopaks by Ficoll-Hypaque density centrifugation and were purified by adherence to plastic, as previously described [72]. The following cell lines were obtained from the NIH AIDS Research and Reference Reagent Program, Division of AIDS, NIAID, NIH: CD4/CCR5/CXCR4 ${ }^{+}$ TZM-bl HeLa cells from Dr. John C. Kappes, Dr. Xiaoyun Wu and Tranzyme Inc. [73]; U373-MAGICCR5 cells (contributed by Dr. Michael Emerman and Dr. Adam Geballe), are a cell line derived from a glioblastoma that has been modified by stable transfection of LTR- $\beta$-galactosidase which is trans-activated by HIV
Tat in relation to the level of virus replication [74]. U373-MAGI-CCR5 cells also express CD4 and human chemokine receptor CCR5 to enable infection by HIV R5 strains and were maintained in Dulbecco's modified Eagle's medium (DMEM) supplemented with 10\% FBS, $0.2 \mathrm{mg} / \mathrm{mL}$ G418, $0.1 \mathrm{mg} / \mathrm{mL}$ hygromycin, and $1.0 \mu \mathrm{g} /$ $\mathrm{mL}$ puromycin [75]. Rat intestinal epithelial 1 (RIE-1) cells were maintained in DMEM supplemented with $10 \%$ FBS, penicillin, and streptomycin. Primary R5 viruses HIV-SF162 [76] and HIV-SX [72] were purchased from the Virology Core Facility, Center for AIDS Research at Baylor College of Medicine, Houston, TX. HIV-SX stock containing $69.681 \mathrm{ng} / \mathrm{ml}$ of HIV p24 with $6.5 \times 10^{4} \mathrm{TCID}_{50} / \mathrm{ml}$ and HIV-SF162 stock containing $169 \mathrm{ng} / \mathrm{ml}$ of HIV p24 with $4.2 \times 10^{5} \mathrm{TCID}_{50} / \mathrm{ml}$ were used for macrophage and U373 infection experiments at an MOI of 0.1. The following reagents were obtained through the AIDS Research and Reference Reagent Program, Division of AIDS, NIAID, NIH: pNL4-3 from Dr. Malcolm Martin [77] and HIV-LAV [78]. TZM-bl cells 
were transfected with pNL4-3 plasmid to produce infectious NL4-3 virus, an X4 HIV-1 strain. TIMPs were purchased from R\&D Systems, Inc. (Minneapolis, MN 55413). L-685,458 and DAPT were purchased from Sigma-Aldrich (St. Louis, MO).

\section{siRNA transfections}

siRNA SMARTpools targeting candidate host mRNAs were synthesized by Dharmacon (Lafayette, CO). Individual siRNA duplexes targeting ADAM10 mRNA were against positions 1119-1138 (5' CCCAAAGTCTCT CACATTA-3'), 1272-1280 (5'-GGACAAACTTAAC AACAAT-3'), 1591-1609 (GCAAGGGAAGGAATATGTA-3'), and 2070-2088 (5'-GCTAATGGCTGG ATTTATT-3'). TZM-bl and U373 cells were transfected with Lipofectamine 2000 (Invitrogen), using $50 \mathrm{nM}$ siRNA $48 \mathrm{~h}$ before viral infections or harvesting for real time quantitative PCR gene target silencing studies. All macrophage transfections were performed with Oligofectamine (Invitrogen) using $50 \mathrm{nM}$ siRNA $48 \mathrm{~h}$ prior to infection following the manufacturer's recommendations, unless otherwise noted.

\section{Real time quantitative PCR}

Primers and probes for real time PCR were custom ordered from Sigma-Aldrich. Full genomic DNA was isolated from monocyte-derived macrophages or cell lines using the Qiagen Blood and Tissue Kit. Small nongenomic DNA, such as reverse transcribed viral cDNA and 2-LTR circles were isolated using a Qiagen Miniprep kit. To detect full length HIV DNA, primers M667 (5'-GGC TAA CTA GGG AAC CCA CTG-3') and M661 (5'-CCT GCG TCG AGA GAG CTC CTC TGG3') [79], along with probe MH603 (5'-(FAM)-ACA CTA CTT GAA GCA CTC AAG GCA AGC TTT(TAMRA)-3') [80] were used. The primers used to amplify HIV-1 cDNA span the primer binding site (PBS); the only time there is contiguous DNA on both sides of the PBS is when synthesis of both full strands of viral DNA is completed $[29,79]$. To identify 2-LTR circle formation, primers MH535 (5'-AAC TAG GGA ACC CAC TGC TTA AG-3') and MH536 (5'-TCC ACA GAT CAA GGA TAT CTT GTC-3') were used with the MH603 probe [80]. For integration, a two-step PCR reaction was performed. For the initial PCR amplification, Alu forward, (5'-GCC TCC CAA AGT GCT GGG ATT ACA G-3'); and HIV-1 gag reverse, (5'-GCT CTC GCA CCC ATC TCT CTC C-3') primers were used [81]. The second step real-time PCR used the primers LTR forward, (5'-GCC TCA ATA AAG CTT GCC TTG A-3'); and LTR reverse, (5'-TCC ACA CTG ACT AAA AGG GTC TGA-3'); and LTR probe (5'-FAMGCG AGT GCC CGT CTG TTG TGT GAC TCT GGT AAC TAG CTC GC-DBH1-3') [81]. Serial dilutions of purified HIV-SX plasmids were used to generate a standard curve to calculate the total concentration of HIV-1 cDNA in each sample, which is expressed as total fentograms ( $\mathrm{fg}$ ) of cDNA. Total mRNA was isolated from siRNA-transfected cells and primary human macrophages using RNeasy Mini Kits (Qiagen, Inc., Valencia, CA). ADAM10 specific primers and probe were purchased from Applied Biosytems (Carlsbad, CA). All reactions were performed using Applied Biosystems TaqMan Universal Master Mix and run using an Applied Biosystems 7500 Fast Real Time PCR system and 7500 Fast System Software [33]. Silencing of target genes was determined by normalizing target gene expression to GAPDH expression $(\mathrm{n}=3)$.

\section{Flow cytometry}

ADAM10 protein expression was assessed using an analytical flow cytometer in control or ADAM10 siRNA-transfected TZM -bl cells after $48 \mathrm{~h}$. ADAM10 expression in siRNA transfectants was determined by detaching cells in PBS/2 mM EDTA and staining cells using either a mouse anti-human ADAM10 antibody (R\&D Systems, Minneapolis, MN) or an IgG1 isotype control (Southern Biotech, Birmingham, AL), followed by incubation with a phycoerythrin-conjugated rabbit anti-mouse secondary antibody (Jackson ImmunoResearch, West Grove, PA).

\section{HIV-1 p24 assays}

To determine the effect of silencing cellular genes on HIV-1 replication, TZM-bl cells or primary human macrophages were transfected with siRNA SMARTpools for $48 \mathrm{~h}$ prior to infection. TZM-bl cells were seeded into T25 flasks (750,000 cells/flask) and transfected as described above. Subsequently, cells were infected overnight with HIV LAV $(\mathrm{MOI}=1)$ and then seeded into duplicate T75 flasks (1.5 million cells per flask). p24 production was assayed from culture supernatants 3 days post-inoculation using the p24 antigen ELISA system (Beckman/Coulter/Immunotech, Brea, CA) following the manufacturer's protocol. Macrophages were infected in 24-well plates with HIV-SF162, and p24 production was assayed from cell lysates and culture supernatants 4 and 7 days, respectively, post-infection using p24 Capture ELISA (ImmunoDiagnostics, Woburn, MA).

\section{$\beta$-galactosidase assays}

U373-MAGI-CCR5 cells were transfected with ADAM10 or control siRNAs for $48 \mathrm{~h}$, and Tat was expressed by either infection with HIV-SF162 or transfection with a pcDNA3-HIV Tat101-Flag vector (NIH Research and Reference Reagent Program) overnight. At various time points following infection or transfection, cells were lysed and analyzed for $\beta$-galactosidase activity using the 
Beta-Glo Assay System (Promega, Madison, WI) and a Bio-Tek Clarity Microplate Luminometer (pcDNA3-HIV Tat101 Flag transfections) or Dynex MLX Luminometer (SF162 infections).

\section{DNA plasmid transfections}

TZM-bl cells were seeded in 24 well plates at $2 \times 10^{4}$ cells/well, and transfected with 800 ng HIV-SX plasmid DNA using Lipofectamine LTX transfection reagent (Invitrogen) along with Plus reagent (Invitrogen) using the one tube protocol according to manufacturer's specifications. After three days incubation, p24 was measured by using a p24 Capture ELISA (see above).

Transfection of ADAM10 plasmids (wild type and E384A) was performed using Lipofectamine 2000 (Invitrogen) according to manufacturer's protocols. ADAM10 E384A has a point mutation in its metalloprotease domain, rendering it inactive. U373-MAGI-CCR5 cells were plated in 12-well plates. After plasmid transfection, cells were incubated for $48 \mathrm{~h}$ and were then infected with HIV-SF162 (MOI $=0.1)$. Forty-eight hours after infection, a $\beta$-galactosidase assay was used to measure infection in the cells as described above.

\section{Cell toxicity assays}

The toxicity of siRNA treatment was measured by aCella-Tox bioluminescence Cytotoxicity Assay (Cell Technology Inc, Mountain View, CA), which detects secreted Glyceraldehyde-3-Phosphate Dehydrogenase (GAPDH) in cells with diminished membrane integrity. Values for released GAPDH were normalized to cellular GAPDH levels.

\section{Statistics}

All statistics were performed using a two-tailed, paired Student's T-Test $\left(* \mathrm{P}<0.05,{ }^{* *} \mathrm{P}<0.01\right)$.

\section{Acknowledgements}

This work was supported by Public Health Service Small Business Innovation Research (SBIR) grant Al084705 from Division of AIDS, National Institute of Allergy and Infectious Diseases. This work was also partly supported by Public Health Service grant HL088999 from the National Heart, Lung, and Blood Institute. We would like to thank Merck \& Co., Inc. for generously providing raltegravir and Dr. Stefan Lichtenthaler (LMU Munich, Germany) for generously providing both ADAM10 wt and ADAM10 E384A plasmids. We thank Edward Siwak, Ph.D., Associate Director of Virology Core Facility, Center for AIDS Research at Baylor College of Medicine, Houston, TX for providing HIV-SX and HIV-SF162. D.H.R. was supported by the Department of Veterans Affairs and gifts from Maggie Chassman, Buisson Foundation, Zirus, and the Public Health Service.

\section{Author details}

${ }^{1}$ Departments of Pathology and Internal Medicine, University of Texas Medical Branch, 301 University Blvd, Galveston, TX, 77555, USA. '2Zirus, Inc., 1384 Buford Business Boulevard, Suite 700, Buford, GA, 30518, USA. ${ }^{3}$ Departments of Medicine and Microbiology \& Immunology, Vanderbilt University, 1161 21st Ave South, Nashville, TN, 37232, USA. ${ }^{4}$ Research Medicine, VA Tennessee Valley Healthcare System, 1310 24th Ave South,
}

Nashville, TN 37212, USA. ${ }^{5}$ Department of Medicine, Division of Infectious Diseases, Emory University School of Medicine, 201 Dowman Dr., Atlanta, GA, 30322, USA.

\section{Authors' contributions}

BF performed the macrophage and U373 cell experiments and drafted the manuscript. JLM performed the TZM-bl experiments, helped draft the manuscript, and participated in the design of the study. GL helped with the macrophage experiments. JS performed gene trap studies implicating ADAM10 in reovirus replication. TWH, DHR, WAO, and MRF all participated in the design and coordination of the study and helped draft the manuscript. All authors read and approved the final manuscript.

\section{Competing Interests}

D.H.R. is the scientific founder of Zirus, Inc., and J.L.M., D.H.R., T.W.H., and W. A.O. have equity in the company. Zirus, Inc. holds intellectual patents to ADAM10.

All other authors declare no competing interests.

Received: 11 November 2010 Accepted: 11 May 2011

Published: 11 May 2011

\section{References}

1. Murray JL, Mavrakis M, McDonald NJ, Yilla M, Sheng J, Bellini WJ, Zhao L, Le Doux JM, Shaw MW, Luo CC, et al: Rab9 GTPase is required for replication of human immunodeficiency virus type 1, filoviruses, and measles virus. J Virol 2005, 79:11742-11751.

2. Organ EL, Sheng J, Ruley HE, Rubin DH: Discovery of mammalian genes that participate in virus infection. BMC Cell Biol 2004, 5:41.

3. Sheng J, Organ EL, Hao C, Wells KS, Ruley HE, Rubin DH: Mutations in the IGF-II pathway that confer resistance to lytic reovirus infection. BMC Cell Biol 2004, 5:32.

4. Brass AL, Dykxhoorn DM, Benita Y, Yan N, Engelman A, Xavier RJ, Lieberman J, Elledge SJ: Identification of host proteins required for HIV infection through a functional genomic screen. Science 2008, 319:921-926.

5. Bushman FD, Malani N, Fernandes J, D'Orso I, Cagney G, Diamond TL, Zhou H, Hazuda DJ, Espeseth AS, Konig R, et al: Host cell factors in HIV replication: meta-analysis of genome-wide studies. PLoS Pathog 2009, 5: e1000437.

6. Konig R, Zhou Y, Elleder D, Diamond TL, Bonamy GM, Irelan JT, Chiang CY, Tu BP, De Jesus PD, Lilley CE, et al: Global analysis of host-pathogen interactions that regulate early-stage HIV-1 replication. Cell 2008, 135:49-60.

7. Zhou H, Xu M, Huang Q, Gates AT, Zhang XD, Castle JC, Stec E, Ferrer M, Strulovici B, Hazuda DJ, Espeseth AS: Genome-scale RNAi screen for host factors required for HIV replication. Cell Host Microbe 2008, 4:495-504.

8. Yeung ML, Houzet L, Yedavalli VS, Jeang KT: A genome-wide short hairpin RNA screening of jurkat T-cells for human proteins contributing to productive HIV-1 replication. J Biol Chem 2009, 284:19463-19473.

9. Goodarzi G, Im GJ, Brackmann K, Grandgenett D: Concerted integration of retrovirus-like DNA by human immunodeficiency virus type 1 integrase. J Virol 1995, 69:6090-6097.

10. Greene WC: The molecular biology of human immunodeficiency virus type 1 infection. N Engl J Med 1991, 324:308-317.

11. Weiner DB, Huebner K, Williams WV, Greene Ml: Human genes other than CD4 facilitate HIV-1 infection of murine cells. Pathobiology 1991, 59:361-371.

12. Zhang H, Zhang Y, Spicer TP, Abbott LZ, Abbott M, Poiesz BJ: Reverse transcription takes place within extracellular HIV-1 virions: potential biological significance. AIDS Res Hum Retroviruses 1993, 9:1287-1296.

13. Murphy G: The ADAMs: signalling scissors in the tumour microenvironment. Nat Rev Cancer 2008, 8:929-941.

14. Bozkulak EC, Weinmaster G: Selective use of ADAM10 and ADAM17 in activation of Notch1 signaling. Mol Cell Biol 2009, 29:5679-5695.

15. Bech-Serra JJ, Santiago-Josefat B, Esselens C, Saftig P, Baselga J, Arribas J, Canals F: Proteomic identification of desmoglein 2 and activated leukocyte cell adhesion molecule as substrates of ADAM17 and ADAM10 by difference gel electrophoresis. Mol Cell Biol 2006, 26:5086-5095.

16. Dyczynska E, Sun D, Yi H, Sehara-Fujisawa A, Blobel CP, Zolkiewska A: Proteolytic processing of delta-like 1 by ADAM proteases. J Biol Chem 2007, 282:436-444 
17. Gutwein P, Mechtersheimer S, Riedle S, Stoeck A, Gast D, Joumaa S, Zentgraf $\mathrm{H}$, Fogel M, Altevogt DP: ADAM10-mediated cleavage of L1 adhesion molecule at the cell surface and in released membrane vesicles. Faseb J 2003, 17:292-294.

18. Li N, Wang Y, Forbes K, Vignali KM, Heale BS, Saftig P, Hartmann D, Black RA, Rossi JJ, Blobel CP, et al: Metalloproteases regulate T-cell proliferation and effector function via LAG-3. Embo J 2007, 26:494-504.

19. Ludwig A, Hundhausen C, Lambert MH, Broadway N, Andrews RC, Bickett DM, Leesnitzer MA, Becherer JD: Metalloproteinase inhibitors for the disintegrin-like metalloproteinases ADAM10 and ADAM17 that differentially block constitutive and phorbol ester-inducible shedding of cell surface molecules. Comb Chem High Throughput Screen 2005, 8:161-171.

20. Vincent B, Paitel E, Saftig P, Frobert Y, Hartmann D, De Strooper B, Grassi J, Lopez-Perez E, Checler F: The disintegrins ADAM10 and TACE contribute to the constitutive and phorbol ester-regulated normal cleavage of the cellular prion protein. J Biol Chem 2001, 276:37743-37746.

21. Arima T, Enokida H, Kubo H, Kagara I, Matsuda R, Toki K, Nishimura H, Chiyomaru T, Tatarano S, Idesako T, et al: Nuclear translocation of ADAM10 contributes to the pathogenesis and progression of human prostate cancer. Cancer Sci 2007, 98:1720-1726.

22. McCulloch DR, AkI P, Samaratunga H, Herington AC, Odorico DM: Expression of the disintegrin metalloprotease, ADAM-10, in prostate cancer and its regulation by dihydrotestosterone, insulin-like growth factor I, and epidermal growth factor in the prostate cancer cell model LNCaP. Clin Cancer Res 2004, 10:314-323.

23. Tousseyn $T$, Thathiah A, Jorissen $E$, Raemaekers $T$, Konietzko U, Reiss $K$ Maes E, Snellinx A, Serneels L, Nyabi O, et al: ADAM10, the rate-limiting protease of regulated intramembrane proteolysis of Notch and other proteins, is processed by ADAMS-9, ADAMS-15, and the gammasecretase. J Biol Chem 2009, 284:11738-11747.

24. Rubin DH, Ruley HE: Cellular genetics of host susceptibility and resistance to virus infection. Crit Rev Eukaryot Gene Expr 2006, 16:155-170.

25. Dalgleish AG, Beverley PC, Clapham PR, Crawford DH, Greaves MF, Weiss RA: The CD4 (T4) antigen is an essential component of the receptor for the AIDS retrovirus. Nature 1984, 312:763-767.

26. Lambert DW, Yarski M, Warner FJ, Thornhill P, Parkin ET, Smith Al, Hooper NM, Turner AJ: Tumor necrosis factor-alpha convertase (ADAM17) mediates regulated ectodomain shedding of the severe-acute respiratory syndrome-coronavirus (SARS-CoV) receptor, angiotensinconverting enzyme-2 (ACE2). J Biol Chem 2005, 280:30113-30119.

27. Ogbomo H, Hahn A, Geiler J, Michaelis M, Doerr HW, Cinatl J Jr: NK sensitivity of neuroblastoma cells determined by a highly sensitive coupled luminescent method. Biochem Biophys Res Commun 2006, 339:375-379.

28. Vachon E, Martin R, Plumb J, Kwok V, Vandivier RW, Glogauer M, Kapus A, Wang X, Chow CW, Grinstein S, Downey GP: CD44 is a phagocytic receptor. Blood 2006, 107:4149-4158.

29. O'Brien WA, Namazi A, Kalhor H, Mao SH, Zack JA, Chen IS: Kinetics of human immunodeficiency virus type 1 reverse transcription in blood mononuclear phagocytes are slowed by limitations of nucleotide precursors. J Virol 1994, 68:1258-1263.

30. Collin M, Gordon S: The kinetics of human immunodeficiency virus reverse transcription are slower in primary human macrophages than in a lymphoid cell line. Virology 1994, 200:114-120.

31. Bukrinsky M, Sharova $N$, Stevenson M: Human immunodeficiency virus type 1 2-LTR circles reside in a nucleoprotein complex which is different from the preintegration complex. J Virol 1993, 67:6863-6865.

32. Farnet CM, Haseltine WA: Circularization of human immunodeficiency virus type 1 DNA in vitro. J Virol 1991, 65:6942-6952

33. Friedrich B, Li G, Dziuba N, Ferguson MR: Quantitative PCR used to assess HIV-1 integration and 2-LTR circle formation in human macrophages, peripheral blood lymphocytes and a CD4+ cell line. Virol J 2010, 7:354

34. Chackerian B, Long EM, Luciw PA, Overbaugh J: Human immunodeficiency virus type 1 coreceptors participate in postentry stages in the virus replication cycle and function in simian immunodeficiency virus infection. J Virol 1997, 71:3932-3939.

35. Folks TM, Justement J, Kinter A, Dinarello CA, Fauci AS: Cytokine-induced expression of HIV-1 in a chronically infected promonocyte cell line. Science 1987, 238:800-802.
36. Folks TM, Justement J, Kinter A, Schnittman S, Orenstein J, Poli G, Fauci AS: Characterization of a promonocyte clone chronically infected with HIV and inducible by 13-phorbol-12-myristate acetate. J Immunol 1988, 140:1117-1122.

37. Postina R, Schroeder A, Dewachter I, Bohl J, Schmitt U, Kojro E, Prinzen C, Endres K, Hiemke C, Blessing M, et al: A disintegrin-metalloproteinase prevents amyloid plaque formation and hippocampal defects in an Alzheimer disease mouse model. J Clin Invest 2004, 113:1456-1464.

38. Amour A, Knight CG, Webster A, Slocombe PM, Stephens PE, Knauper V, Docherty AJ, Murphy G: The in vitro activity of ADAM-10 is inhibited by TIMP-1 and TIMP-3. FEBS Lett 2000, 473:275-279.

39. Hansson CA, Frykman S, Farmery MR, Tjernberg LO, Nilsberth C, Pursglove SE, Ito A, Winblad B, Cowburn RF, Thyberg J, Ankarcrona M: Nicastrin, presenilin, APH-1, and PEN-2 form active gamma-secretase complexes in mitochondria. J Biol Chem 2004, 279:51654-51660.

40. Lai MT, Chen E, Crouthamel MC, DiMuzio-Mower J, Xu M, Huang Q, Price E, Register RB, Shi XP, Donoviel DB, et al: Presenilin-1 and presenilin-2 exhibit distinct yet overlapping gamma-secretase activities. $J$ Biol Chem 2003, 278:22475-22481

41. Kanungo J, Zheng YL, Amin ND, Pant HC: The Notch signaling inhibitor DAPT down-regulates cdk5 activity and modulates the distribution of neuronal cytoskeletal proteins. J Neurochem 2008, 106:2236-2248.

42. Shearman MS, Beher D, Clarke EE, Lewis HD, Harrison T, Hunt P, Nadin A, Smith AL, Stevenson G, Castro JL: L-685,458, an aspartyl protease transition state mimic, is a potent inhibitor of amyloid beta-protein precursor gamma-secretase activity. Biochemistry 2000, 39:8698-8704.

43. Ding C, Maier E, Roscher AA, Braun A, Cantor CR: Simultaneous quantitative and allele-specific expression analysis with real competitive PCR. BMC Genet 2004, 5:8.

44. Gregg C, Zhang J, Butler JE, Haig D, Dulac C: Sex-specific parent-of-origin allelic expression in the mouse brain. Science 2010, 329:682-685.

45. Palacios R, Gazave E, Goni J, Piedrafita G, Fernando O, Navarro A, Villoslada P: Allele-specific gene expression is widespread across the genome and biological processes. PLoS One 2009, 4:e4150.

46. Miyoshi H, Shimizu K, Kozu T, Maseki N, Kaneko Y, Ohki M: t(8;21) breakpoints on chromosome 21 in acute myeloid leukemia are clustered within a limited region of a single gene, AML1. Proc Natl Acad Sci USA 1991, 88:10431-10434.

47. Osato M, Asou N, Abdalla E, Hoshino K, Yamasaki H, Okubo T, Suzushima H, Takatsuki K, Kanno T, Shigesada K, Ito Y: Biallelic and heterozygous point mutations in the runt domain of the AML1/PEBP2alphaB gene associated with myeloblastic leukemias. Blood 1999, 93:1817-1824.

48. von Lindern JJ, Rojo D, Grovit-Ferbas K, Yeramian C, Deng C, Herbein G Ferguson MR, Pappas TC, Decker JM, Singh A, et al: Potential role for CD63 in CCR5-mediated human immunodeficiency virus type 1 infection of macrophages. J Virol 2003, 77:3624-3633.

49. Singh $M$, Mukherjee $P$, Narayanasamy $K$, Arora $R$, Sen SD, Gupta S, Natarajan K, Malhotra P: Proteome analysis of Plasmodium falciparum extracellular secretory antigens at asexual blood stages reveals a cohort of proteins with possible roles in immune modulation and signaling. $\mathrm{Mol}$ Cell Proteomics 2009, 8:2102-2118.

50. Budagian V, Bulanova $E$, Orinska Z, Duitman $E$, Brandt $K$, Ludwig A, Hartmann D, Lemke G, Saftig P, Bulfone-Paus S: Soluble Axl is generated by ADAM10-dependent cleavage and associates with Gas 6 in mouse serum. Mol Cell Biol 2005, 25:9324-9339.

51. Hakulinen J, Keski-Oja J: ADAM10-mediated release of complement membrane cofactor protein during apoptosis of epithelial cells. $J$ Biol Chem 2006, 281:21369-21376.

52. Hattori M, Osterfield M, Flanagan JG: Regulated cleavage of a contactmediated axon repellent. Science 2000, 289:1360-1365

53. Hikita A, Yana I, Wakeyama H, Nakamura M, Kadono Y, Oshima Y, Nakamura K, Seiki M, Tanaka S: Negative regulation of osteoclastogenesis by ectodomain shedding of receptor activator of NF-kappaB ligand. J Biol Chem 2006, 281:36846-36855.

54. Hinkle CL, Diestel S, Lieberman J, Maness PF: Metalloprotease-induced ectodomain shedding of neural cell adhesion molecule (NCAM). J Neurobiol 2006, 66:1378-1395.

55. Hundhausen C, Misztela D, Berkhout TA, Broadway N, Saftig P, Reiss K, Hartmann D, Fahrenholz F, Postina R, Matthews V, et al: The disintegrin-like metalloproteinase ADAM10 is involved in constitutive cleavage of 
CX3CL1 (fractalkine) and regulates CX3CL1-mediated cell-cell adhesion. Blood 2003, 102:1186-1195.

56. Lammich S, Kojro E, Postina R, Gilbert S, Pfeiffer R, Jasionowski M, Haass C, Fahrenholz F: Constitutive and regulated alpha-secretase cleavage of Alzheimer's amyloid precursor protein by a disintegrin metalloprotease. Proc Natl Acad Sci USA 1999, 96:3922-3927.

57. Liu PC, Liu X, Li Y, Covington M, Wynn R, Huber R, Hillman M, Yang G, Ellis D, Marando C, et al: Identification of ADAM10 as a major source of HER2 ectodomain sheddase activity in HER2 overexpressing breast cancer cells. Cancer Biol Ther 2006, 5:657-664.

58. Loesch K, Deng L, Cowan JW, Wang X, He K, Jiang J, Black RA, Frank SJ: Janus kinase 2 influences growth hormone receptor metalloproteolysis. Endocrinology 2006, 147:2839-2849.

59. Maretzky T, Reiss K, Ludwig A, Buchholz J, Scholz F, Proksch E, de Strooper B, Hartmann D, Saftig P: ADAM10 mediates E-cadherin shedding and regulates epithelial cell-cell adhesion, migration, and beta-catenin translocation. Proc Natl Acad Sci USA 2005, 102:9182-9187.

60. Nagano O, Murakami D, Hartmann D, De Strooper B, Saftig P, Iwatsubo T, Nakajima M, Shinohara M, Saya H: Cell-matrix interaction via CD44 is independently regulated by different metalloproteinases activated in response to extracellular $\mathrm{Ca}(2+)$ influx and PKC activation. J Cell Biol 2004, 165:893-902.

61. Reiss K, Maretzky T, Haas IG, Schulte M, Ludwig A, Frank M, Saftig P: Regulated ADAM10-dependent ectodomain shedding of gammaprotocadherin C3 modulates cell-cell adhesion. J Biol Chem 2006, 281:21735-21744.

62. Reiss K, Maretzky T, Ludwig A, Tousseyn T, de Strooper B, Hartmann D, Saftig P: ADAM10 cleavage of $\mathrm{N}$-cadherin and regulation of cell-cell adhesion and beta-catenin nuclear signalling. Embo J 2005, 24:742-752.

63. Sanderson MP, Abbott CA, Tada H, Seno M, Dempsey PJ, Dunbar AJ: Hydrogen peroxide and endothelin-1 are novel activators of betacellulin ectodomain shedding. J Cell Biochem 2006, 99:609-623.

64. Weskamp G, Ford JW, Sturgill J, Martin S, Docherty AJ, Swendeman S, Broadway N, Hartmann D, Saftig P, Umland S, et al: ADAM10 is a principal 'sheddase' of the low-affinity immunoglobulin E receptor CD23. Nat Immunol 2006, 7:1293-1298.

65. Yan Y, Shirakabe K, Werb Z: The metalloprotease Kuzbanian (ADAM10) mediates the transactivation of EGF receptor by $\mathrm{G}$ protein-coupled receptors. J Cell Biol 2002, 158:221-226.

66. Janes PW, Wimmer-Kleikamp SH, Frangakis AS, Treble K, Griesshaber B, Sabet O, Grabenbauer M, Ting AY, Saftig P, Bastiaens PI, Lackmann M: Cytoplasmic relaxation of active Eph controls ephrin shedding by ADAM10. PLOS Biol 2009, 7:e1000215.

67. Liu Q, Zhang J, Tran H, Verbeek MM, Reiss K, Estus S, Bu G: LRP1 shedding in human brain: roles of ADAM10 and ADAM17. Mol Neurodegener 2009, 4:17.

68. Martin $L$, Fluhrer R, Reiss $K$, Kremmer E, Saftig P, Haass C: Regulated intramembrane proteolysis of Bri2 (Itm2b) by ADAM10 and SPPL2a/ SPPL2b. J Biol Chem 2008, 283:1644-1652.

69. Geijtenbeek TB, Kwon DS, Torensma R, van Vliet SJ, van Duijnhoven GC, Middel J, Cornelissen IL, Nottet HS, KewalRamani VN, Littman DR, et al: DCSIGN, a dendritic cell-specific HIV-1-binding protein that enhances transinfection of T cells. Cell 2000, 100:587-597.

70. Pohlmann S, Soilleux EJ, Baribaud F, Leslie GJ, Morris LS, Trowsdale J, Lee B, Coleman N, Doms RW: DC-SIGNR, a DC-SIGN homologue expressed in endothelial cells, binds to human and simian immunodeficiency viruses and activates infection in trans. Proc Natl Acad Sci USA 2001, 98:2670-2675.

71. Cousin H, Abbruzzese G, Kerdavid E, Gaultier A, Alfandari D: Translocation of the Cytoplasmic Domain of ADAM13 to the Nucleus Is Essential for Calpain8-a Expression and Cranial Neural Crest Cell Migration. Dev Cell 2011, 20:256-263.

72. O'Brien WA, Koyanagi Y, Namazie A, Zhao JQ, Diagne A, Idler K, Zack JA, Chen IS: HIV-1 tropism for mononuclear phagocytes can be determined by regions of gp120 outside the CD4-binding domain. Nature 1990, 348:69-73.

73. Takeuchi Y, McClure MO, Pizzato M: Identification of gammaretroviruses constitutively released from cell lines used for human immunodeficiency virus research. J Virol 2008, 82:12585-12588.
74. Harrington RD, Geballe AP: Cofactor requirement for human immunodeficiency virus type 1 entry into a CD4-expressing human cell line. J Virol 1993, 67:5939-5947.

75. McDonald D, Vodicka MA, Lucero G, Svitkina TM, Borisy GG, Emerman M, Hope TJ: Visualization of the intracellular behavior of HIV in living cells. J Cell Biol 2002, 159:441-452.

76. Shioda T, Levy JA, Cheng-Mayer C: Macrophage and T cell-line tropisms of HIV-1 are determined by specific regions of the envelope gp120 gene. Nature 1991, 349:167-169.

77. Adachi A, Gendelman HE, Koenig S, Folks T, Willey R, Rabson A, Martin MA: Production of acquired immunodeficiency syndrome-associated retrovirus in human and nonhuman cells transfected with an infectious molecular clone. J Virol 1986, 59:284-291.

78. Barre-Sinoussi F, Chermann JC, Rey F, Nugeyre MT, Chamaret S, Gruest J, Dauguet C, Axler-Blin C, Vezinet-Brun F, Rouzioux C, et al: Isolation of a Tlymphotropic retrovirus from a patient at risk for acquired immune deficiency syndrome (AIDS). Science 1983, 220:868-871.

79. Zack JA, Arrigo SJ, Weitsman SR, Go AS, Haislip A, Chen IS: HIV-1 entry into quiescent primary lymphocytes: molecular analysis reveals a labile, latent viral structure. Cell 1990, 61:213-222.

80. Butler SL, Hansen MS, Bushman FD: A quantitative assay for HIV DNA integration in vivo. Nat Med 2001, 7:631-634.

81. O'Doherty U, Swiggard WJ, Jeyakumar D, McGain D, Malim MH: A sensitive, quantitative assay for human immunodeficiency virus type 1 integration. J Virol 2002, 76:10942-10950.

doi:10.1186/1742-4690-8-32

Cite this article as: Friedrich et al: A Functional Role for ADAM10 in Human Immunodeficiency Virus Type-1 Replication. Retrovirology 2011 8:32.

\section{Submit your next manuscript to BioMed Central and take full advantage of:}

- Convenient online submission

- Thorough peer review

- No space constraints or color figure charges

- Immediate publication on acceptance

- Inclusion in PubMed, CAS, Scopus and Google Scholar

- Research which is freely available for redistribution 